\title{
Polish electoral system to self local government - changes and effects
}

\section{Beata Słobodzian ${ }^{1}$}

\begin{abstract}
Poland as a young democracy is supported by extensive experience of mature democratic systems. Poland is still seeking reasonable and effective solutions regarding its electoral system. The right for electing the representatives of authority bodies is one of the fundamentals of democracy. This right entitles citizens for active public participation through expressing their support (votes) for candidates, which will respectively represent their voters in certain institutions. Polish electoral law, which regulates the local self-government elections is very controversial. The existing legal rules have been changed many times since 2011. Among the subjects being discussed are electoral campaigns, and candidate registration rules and organization of elections. Frequent changes in the electoral law result in misunderstandings and an unwillingness to participate in elections. Their effect is low voter turnout and a large number of invalid votes. Regardless of the above, it is worth to consider, why the Electoral Code was prepared so chaotically and without any further discussion? Why before the forthcoming elections to the European Parliament and municipalities planned for 2014 it was not possible to be assured about the electoral regulations, which were the subject of numerous changes?
\end{abstract}

Key words: Republic of Poland; elections, electoral law, election system, local selfgovernance.

\section{INTRODUCTION}

Local self-government constitutes a crucial link to shaping a democratic state. It is one of the forms of devolution of power. As far as its history is concerned, it was established in order to enable bodies of authority to complete tasks of a local character, which in fact central authorities could not realize properly. The local selfgovernment performs its mission through local authorities. According to Polish law (The Constitution of the Republic of Poland of 1997), the bodies of authority include: decision-making bodies - selected through indirect elections, as well as, implementing bodies - selected on the basis of appropriate regulations. The reactivation of Polish self-government, which took place in 1990, was associated

1 Beata Słobodzian, Ph.D., Departament of Political Science, Univercity of Gdańsk, Bażynskiego 4 Str., 80-309 Gdansk, Poland. e-mail: polbsl@univ.gda.pl 
with i.a. conduction of local elections. The first local elections were conducted on 27 May 1990, when representatives (councillors) of Municipality Councils were selected. As for collective implementing bodies (Council Boards) they were chosen in direct elections. Within several next years the local electoral law was amended. Finally, in 2002 a new procedure of elections for implementing bodies in municipalities was launched. The collective Council Board was changed into a single-implementing body (a vogt, a mayor and a president of a city) that was selected in indirect elections. In consequence, the aforesaid change of procedure had a strong impact on a higher voter turnout and engagement of citizens in local issues. Other amendments to the electoral law were of character 'tailored' for the necessities of certain political parties, which sought to gain a power in the state.

\section{THE ELECTORAL SYSTEM AND THE CHANGES MADE}

The right for electing representatives of authority bodies is one of the fundamentals of democracy. This right entitles citizens for active public participation through expressing their support (votes) for candidates, which will respectively represent their voters in certain institutions. The essence of democracy is identified with a wise, aware and trustworthy participation of main actors of a public sphere, citizens, political parties as well as media in the procedures of the system (Fras, 7). The right of election, which specifies terms and conditions of selecting representative bodies, is a basis of a democratic state based on the rule of law. Furthermore, it is also a guarantee of realization of numerous regulations, rules and constitutional values including these crucial civil rights and liberties (The Electoral Code of 2015).

On the one hand, as a young democracy supported by an extensive experience of mature democratic systems, Poland is still seeking reasonable and effective solutions regarding their electoral system. On the other hand, the quality of Polish electoral law, the number of amendments and last, but not least - the reasons of implementation of these amendments - are the main factors to assume that it is only a 'tool' used by politicians in order to achieve a dominant position (majority of seats in Parliament) in the structures of the public institutions.

The very first conduction of municipal elections in Poland was on 27 May 1990 (DzU1990.16.96) and is thought to be a victory achieved after electoral combat regarding implementation of system reforms. Regardless of the above, it was considered to be 'a defeat of engagement of local communities'. The impact on the low electoral frequency amounting to $42.27 \%$ citizens entitled to vote was 
identified with inappropriate provisions regarding the organization of elections:

- the poling places were opened until 8.00 p.m., which constituted a certain difficulty for citizens living outside the place of their permanent residence;

- an exclusion of the possibility of voting in the other municipal units than a permanent residence, e.g. students, citizens working outside their permanent residence, Army conscripts, hospitalized citizens or citizens on a holiday leave were deprived of their active electoral right.

Nevertheless, the main advantage of the aforesaid elections was a possibility to nominate candidates for Councillors by civil committees and groups of citizens (Article 31), which achieved $48.6 \%$ votes (including 38\% of candidates, who were nominated for independent seat) (Regulski, 2000, 101-102).

For municipalities up to 40,000 inhabitants the single-seat constituencies were created with usage of majority voting (Article 8 Paragraph. 1). In terms of bigger municipalities (reaching more than 40,000 inhabitants) a proportional system was implemented. Therefore, seats were distributed accordingly with Sainte-Lague's method (Article 91 Paragraph 1 Point 1).

The necessity of conducting second municipal elections in row I 1994 increased disputes pertaining to a change of electoral regulations. The suggested solutions as well as their quality and quantity might have been the reason of encouragement for participation in the above elections. The following amendments were suggested:

- the implementation of homogenous proportional system with usage of d'Hondt's method or Sainte-Lague's method; however at the same time in terms of municipalities up to 15,000 or 20,000 inhabitants a mixture of majority and proportional system shall be retained;

- the change of single-seat constituencies to 1-5 seats constituencies;

- the possibility of dismissal of a councillor, who is inactive for more than 9 months, by members of municipal council. Furthermore, it was suggested that the above appeal should be supported by $10 \%$ of electors;

- the prohibition of conduction of political campaigns in places for religious worship (Sejm RP, 291A). 
The issue of amended regulations regarding municipal elections was undertaken in 1998, when new elections were conducted (in June 1998 the term of office of then municipal councils expired). Moreover, in 1998 works regarding the increase of state's decentralization and implementation of municipalities. Further to the above, a preparation of public administration reform demanded the inclusion of brand new regulations for municipal elections as well as an amendment to regulations pertaining to local referendum. The projects of municipal voting systems, which where then taken into account, included different solutions in terms of:

- a character of elections (majority, proportional);

- a distribution of seats (d'Hondt's methods, Sainte-Lague's method);

- a height of thresholds regarding the size of municipality (for majority elections);

- a size of constituencies (single, 1-5, 3-5 seats);

- an implementation of electoral thresholds for lists - amounting to 3\%. (Słobodzian, 2005, 153-155) ${ }^{2}$.

Finally, on 16 July 1998 the Seym (parliament) has accepted the Act on Elections to Municipal and County Councils and Provincial Assemblies, which constituted a basis of conduction of new municipal elections, dated 11 December 1998 (DzU 1998.50.311). The electoral frequency amounted relatively to: $45.45 \%$ for municipal councils, $47.76 \%$ for district councils and $45.37 \%$ for voivodeship councils (Słobodzian, 2005, 228).

Thanks to an implementation of a new administrative-territorial division of a state as well as construction of supragmina units, the rule of indirect citizens' participation in elections was extended. The further development of this rule was embodied with acceptance of the Act on indirect elections of town and village mayors and presidents in 2002 (DzU 2002.113.984). Therefore, the local communities were given a right of indirect election of local authorities. At the same time a then applicable model of collegiate bodies selected in direct elections by councillors was rejected. The implementation of a change to electoral procedure regarding local executive authorities stopped the 'illegible'

2 The overall objective, which led the reformers, was an adoption of law-electoral authorities of all local government units. This was possible thanks to the shift in the timeframe of the elections. The amendment to the electoral law of 1990, introduced on 20 March 1998, allowed conducting elections in the autumn. The Act of 20 March 1998 amending the Act - Elections to municipal councils, (Journal of Laws of 1998 No. 50, Item. 311). 
rules of direct elections.

Political parties (together with coalitions) as well as social organizations and voters were given the right of reporting candidates for the positions of local mayors (Article 7 Paragraph 1). The winning candidate was supposed to obtain more than $50 \%$ valid votes (Article 4 Paragraph 1). In case when elections were not resolved, the necessity to conduct a so-called second ballot prior to 14 days after the first round of voting was implemented. In the second ballot only two candidates, who achieved the highest votes in the first round, were taken into account. It is worth to mention that the rules of second ballot is based on the majority system. These rules were supposed to increase engagement of local communities in a process of election of local authorities.

In autumn 2006 local elections were announced. It was the third time when candidates to councils were selected and the second time when local communities voted for their future village and town mayors as well as presidents. The above elections were conducted accordingly with the amended rules of constituencies from 1998 and 2002. An amendment of the regulations made it less transparent and understandable for an average voter. An institution of blocking electoral lists of candidates reported in local elections was treated as a brand new rule. In territorial units amounting up to 20,000 inhabitants, districts and voivodeship (the highest-level administrative subdivision of Poland, corresponding to a "province") councils the proportional system was introduced; however the extent of 5\% electoral threshold was launched in units up to 20,000 inhabitants (DzU 2004.102.1055). In addition, an obligation of registration in local electoral committee was implemented in the above-mentioned units.

An analysis of changes introduced in regulations regarding local elections indicated that these electoral rules were close to the proportional system, which in the opinion of politicians 'helped to understand the local, district and province political scene' as well as 'provided better identification of candidates and submitted more complex representation of different groups of local communities' (Sejm RP, 1998). The 5\% threshold provisions (amounting relatively 10\% for territorial units up to 20,000 inhabitants and for districts, as well as, $15 \%$ for province councils), the method of votes' distribution to seats and a size of constituencies resulted in an improvement of quality of local political scene.

Suffrage is guaranteed in the Constitution of the Republic of Poland dated 2 April 1997 (DzU 1997.78.483) (Article 62 Paragraph 1): If, no later than on the day of vote, he has attained 18 years of age, Polish citizen shall have the right to participate in a referendum and the right to vote for the President of the Republic of Poland as well as representatives to the Sejm and Senate and organs of local 
government and the other detailed legislations.

Local authorities are one of the most important public institutions. Their representatives are elected in general elections. The above elections are regularly announced every 4 years and are guaranteed by the regulations of the Constitution of the Republic of Poland (Article 169) and the other regulations. According to the Constitution the bodies of local authority are divided into: decisionmaking bodies - chosen in the general, equal, indirect and secret elections, as well as executive bodies - which election is specified by the regulations. After introduction of the reform of public administration (since 1 January 1999) and brand new election act dated 2002, a new structure of local authorities was established. The decision-making bodies are municipal, district and province councils. Whereas the executive bodies are village and town mayors and presidents, who are chosen in a procedure of indirect elections, as well as district and province boards - collegiate bodies including representatives selected in direct elections A crucial change of Polish election law was an adoption of a new law - the Electoral Code of the Republic of Poland. It meant at the same time a rejection of the then applicable and separate acts regulating terms and conditions of electing authorities, inter alia:

a) the Act on Presidential election dated 27 September 1990 (DzU 2010.72.467.)

b) the Act on Elections Municipal and County Councils and Provincial Authorities dates 16 July 1998 (DzU 2010.176.1190)

c) the Act on Elections to the Seym of the Republic of Poland and to the Senate of the Republic of Poland dated 12 April 2001 (DzU 2007.190.1360)

d) the Act on Indirect Elections a Head of Commune, a Major and a President of a City dated 20 June 2002 (DzU 2010.176.1191)

e) the Act on Elections to the European Parliament dates 23 January 2004 (DzU 2004.25.219).

A repeal of five electoral acts and substitution of one was a decision made in order to unify a dispersed electoral matter. The new adopted act dated 5 January 2011 (the Electoral Code of the Republic of Poland) (DzU 2011.21.112) was applicable since 1 August 2011. In the first (the Directive 1 - Preliminary provisions and the Directive 2 - Electoral bodies) and the last part (the Directive 9 - Criminal law measures and the Directive 10 - Final provisions) of the Code 
several common matters regulating the elections were included. The other content of the Code pertained to detailed regulations regarding the procedure of election of certain authorities (the Directive 2 - Elections to Seym of the Republic of Poland; the Directive 4 -Elections to the Senate of the Republic of Poland; the Directive 5 - Elections of the President of the Republic of Poland; the Directive 6 - Elections to the European Parliament; the Directive 7 - Elections to bodies of local authorities and the Directive 8 - Elections of a Head of Commune, a Major and a President of a City).

Apparently a huge experience regarding disputes over the electoral law its creation and reforms would not constitute a problem in terms of a unified code. In the case of vacatio legis lasting for 7 years the Electoral Code, which was then not applicable, was amended several times. Nevertheless, the Electoral Code dated 3 February 2011 (DzU 2011.26.134) was a final document, which specified the rules of conduction of electoral campaign. These were not innovative solutions, but regulations, which were apparently neglected in a new code and were applicable in terms of 'repealed electoral acts', e.g. the amendment of Article 161 Paragraph 1 of the Electoral Code remained finally as: 'Electoral committees have the right to disseminate paid broadcasts in the programs of state radio and television broadcasters'. An Article 119 Paragraph 2 the following definition was included: 'a part of radio or television programme, separated and not emitted by a public broadcaster, which was ordered by electoral committee in terms of an electoral campaign, is also considered to be an electoral announcement'. The altered regulations of the Electoral Code were valid in 14 days after announcing them; however, the Constitutional Tribunal questioned them. On the basis of a judgement dated 20 July 2011 (DzU 2011.149.889) the altered Electoral Code was judged to be not in compliance with the Constitution of the Republic of Poland and therefore, on 21 July 2011 it was no longer valid.

Regardless of the above, it is worth to consider, why the Electoral Code was prepared so chaotically and without any further discussion? Why before the forthcoming elections to the European Parliament and municipalities planned for 2014 it was not possible to be assured about the electoral regulations, which were the subject of numerous changes?

Another amendments of the Electoral Code were: an addition of an annexure including a registry of constituencies to the Seym of the Republic of Poland together with the number of deputies (DzU 2011.94.550); a specification of general regulations (DzU 2011.102.588); an extension of regulations, that will enable disabled citizens to participate in elections (DzU 2011.147.881) - a separated chapter (5a) was also added (this chapter also regarded a record and 
tax identification of citizens - hence, an obligation of holding NIP 3 and REGON ${ }^{4}$ numbers was also imposed on registered electoral committees); an introduction of regulations pertaining to terms of office of councillors; a specification of limit of costs incurred by an electoral committee (DzU 2011.171.1016); a verification of European citizens engagement in elections to the European Parliament (DzU 2014.180); possibilities to vote via letter or proxy (Chapter 6a) (DzU 2014.1072).

Before a validation of the Electoral Code in 1 August 2011 its content was amended five times and subsequently, was assessed by the Constitutional Tribunal. Up until 31 December 2014 it was amended for the sixth time and it was twice send back to the Constitutional Tribunal. So many amendments and such a high frequency of alteration of the Electoral Code was not a proof of a high quality. Furthermore, a problem of 'candidates' preparation' to the elections was also raised. Therefore, it was not possible to foresee the new ideas for enhancing elections procedures. As far as voters are concerned, a method and a frequency of changing the electoral law were encouraging to participate in the elections.

Information broadcasted by media was too general and rather alarmed the voters, but did not submit any specific and understandable information regarding electoral problems. A lack of appropriate civil education in terms of the electoral law as well as 'the noise' pertaining to the new form of the Electoral Code, did not whatsoever encourage citizens to vote, e.g. the electoral frequency in the elections to the European Parliament dated 25 May 2014 reached 23.83\%, as well as, in the municipality elections only $47.40 \%$ of citizens (PKW, 2014) took part. The propensity of low frequency has lasted for decades, e.g. in regular municipality elections each 4 years en electoral frequency has not exceeded $50 \%$. This can confirm a lack of civil engagement in local issues. On the one hand, public authorities can be blamed for not stimulating the engagement of citizens; however, on the other hand, voters themselves are guilty of this situation, who due to a possible lack of appropriate knowledge, do not want to have an impact on a political situation in their country.

The crucial change of a quality of municipality elections on a community level was introduction of single-mandate districts (so-called SMDs). This rule was examined before. It was introduced with Article 12 Paragraph 1 of the Act on Elections to Municipal Councils dated 8 March 1990 (DzU 1990.16.96), which regarded municipalities up to 40,000 inhabitants. Another bill dated 16 July 1998 (the Act on Elections to Municipal and County Councils and Provincial Assemblies) mentioned municipal and county councils as the bodies responsible for creation of single-mandate districts (Article 90 Paragraph 1).

3 Polish VAT Identification Number

4 Polish Statistical Identification Number 
According to the regulations of the Electoral Code SMDs pertained to the municipalities, which were not cities with county rights. Only in 201437.842 single-mandate districts were created. The specific rules of municipalities division to constituencies was regulated by the resolution of the State Electoral Commission dated 7 May 2012.5 (MP 2012.354). An authority entitled to divide an area of a municipality is a Municipality or County Councils, which is active on the basis of a request lodged by a vogt (a mayor, a president of a city). The State Electoral Commission recommends the following 'before an application regarding a division of a municipality to single-seat constituencies is submitted to a Municipality or County Council, a vogt should submit the above application compliant with the Constitution to the States Electoral Commission's commissioner. The State Electoral Commission obliges its commissioners to help executive authorities of municipalities to prepare projects of a division of a municipality into constituencies' (point 2). This application is non-binding act for a Municipality or County Council. Moreover, it is possible to introduce amendments regarding a proposed application provided that they are compliant with the Electoral Code. During creation of SMDs a rule of homogenous representative norm calculated on the basis of a quotient of number of inhabitants and number of councillors elected to a specific council (Article 419 of the Electoral Code). Therefore, when planning the division into municipality constituencies, councillors should take into account the number of inhabitants mentioned in an electoral record dated a quarter prior to a quarter of division into municipality constituencies (Article 6 of the States Electoral Commission's regulation). The statutory definition of 'number of inhabitants' means an amount of voters included in the records of voters publicly or by a request, as well as, the rest persons registered for a permanent residence with the exception of persons, for whom notification regarding registration to the other electoral registry was received (Point 6 of the resolution of the State Electoral Commission).

Moreover, several detailed solutions regarding creation of constituencies were implemented, such as recognition of auxiliary units of the municipality as constituencies as for rural areas (Article 415 of the Electoral Code), definition of the rule regarding seats' division after an announcement of the elections' results (Article 443 and 444 of the Electoral Code).

The practice of creation of SMDs means a division of an area of municipality into the number of constituencies amounting to the number of councillors sitting in the Municipality Council. The above reflects that the major rule of this system is the number of inhabitants in a municipality. According to Article 17 of the Local Government Law in municipalities up to 20,000 inhabitants the number 5 Due to the change of territorial division in Poland for Zielona Góra (applicable since 1 January 2015) the local elections were not conducted. 
of councillors amounts to 15 seats; in these up to 50,000 inhabitants - 21 seats; in these up to 100,000 inhabitants -23 seats; in these up to 200,000 inhabitants - 25 seats. Furthermore, 3 additional seats per each 100.000 inhabitants more; however there is a limitation up to 45 seats per municipality. To sum up, the idea of creation SMDs is to give a possibility for reflection pluralism of voters' choices. This also has a strong impact on drawing up electoral lists, creation of electoral committees as well as a direction of electoral campaign.

The weakness of the above-mentioned electoral law base on SMDs is inter alia the issue of vacancy. The expiration of a mandate in such constituencies results in the necessity of announcement and conduction of by-elections. This may lead to a lack stability and disorganisation of Municipality Council and additional costs incurring the state's budget.

There was no such possibility (by-elections) in the current proportional system (for municipalities up to 20,000 inhabitants) owing to the fact that in a case of vacancy a mandate was assigned to another candidate listed in an electoral list, who achieved another score. This mechanism protected against by-elections and guaranteed fast procedure of completion of vacant mandate. In addition, if needed, the list could be 'exhausted' up until the last candidate.

The introduction of SMDs was supposed to result in increase of identification of candidates by voters. According to the rule 'a winner takes it all', SMDs are friendly to electoral selection, a revival of local communities and a change of a mindset of new selected councillors. A councillor by nature would rather identify with a district and its voters than e.g. municipality, which is an amount of constituencies. A will to candidate in another election will result in a higher openness, a care of local issues as a candidate would seek to obtain inhabitants' votes.

A 'construction' of voting cards raises some concerns. The State Electoral Commission, which was obliged to prepare such cards (Article 160 Paragraph 1 Point 6 of the Electoral Code), did not double-check the consistency of an adopted specimen. The adoption of a 'book format', i.e. several stapled pages including each electoral list, was a source of problems of voters as well as members of precinct election commissions. The above-mentioned cards were used during local elections, where proportional system is applied (elections to County Councils and regional assembliesin cities with powiat rights). According to the Electoral Law, e.g. in elections of councillors in cities with powiat rights, a voter should mark one list with a cross (x) in a box on the left side of a candidate's name. This means a priority for a mandate as per Article 440 Paragraph 1 of the Electoral Code. Each additional ' $x$ ' marks on the same or the other list makes a vote invalid. The above information is mentioned in the bottom of each page of 
a voting card. This content, on the other hand, appeared to be illegible for voters and mentioning it on the each page suggested a possibility to vote for a one candidate mentioned in each list.

The 'book format' of the card extended the procedure of voting as well as counting votes due to the fact that after reading this 'book' precinct election commissions in general assign each vote to a candidate and an electoral committee. In practice cards are distributed between members of a commission, who implement different criteria of counting votes. Some of them read the whole 'book'; some of them end counting as soon as they see the first ' $x$ ' mark and then barely verifying whether a vote is valid. Therefore, we may assume that the results of local elections are 'more or less detailed'.

It is worth to consider the other methods of counting votes. Perhaps a card in 'sheet format' or in 'envelope format' would be more useful. The first specimen is a big-sized sheet consisting of all the electoral lists. The second one bases on choosing one list before voting and subsequently, hiding a marked list in an envelope. Additional lists included in an envelope would mean that a vote is invalid. The implementation of one of the above-mentioned methods would be less time-consuming for either voters or members of a precinct election commission.

Checking the completion of cards before voting is one of the most important obligations of a precinct election commission. Each of voting cards delivered to a polling place should be counted, appropriately sealed and verified in terms of a quality of print. A lack of professional preparation of members of a commission results in errors and reflects an irregularity of an electoral procedure.

For instance in local elections dated 16 November 2014 the State Electoral Commission indicated numerous infringements of the electoral procedure, such as (Komisarski, 2014; PKW, 2015):

a) defectively printed voting cards - in such situations election commissions sought to exchange cards for valid ones or to print new ones;

b) deliverance of cards to inappropriate polling places (instead of voting cards to Municipality Councils, cards to District Councils were delivered) or in inappropriate quantity;

c) issuing of voting cards of the wrong constituency;

d) incomplete voting cards lacking on certain lists submitted by electoral committees with pages printed in different colours - this situation was noted in Krakow, Nowy Sącz and Złotów. In three polling places 
in Gdynia some lists included in voting cards for elections to the City Council and to the County Council were doubled, omitted or wrongly stapled. This was a reason of invalidity of voting cards.

e) inappropriate information regarding the voting procedures provided by members of election commissions (regardless of the information mentioned in the bottom of each page of a card);

f) voting cards without seals (e.g. in Radzyń Podlaski - 61 unsealed cards);

g) defectively printed voting cards with a blue colour - in consequence, ' $x$ ' mark was also visible on the other pages of a card and therefore, it was invalid;

h) cancellation on purpose of valid votes by adding ' $x$ ' marks by members of commissions;

i) wrong interpretation of votes by members of commissions.

Regardless of the identification of numerous infringements in the voting procedure, notification to the competent authorities, which are obliged to prevent elections from such situations, as well as, an exposure of these issues in media, it was not possible to establish 'the ideal' electoral system. A defective electoral law, a lack of supervision over the voting procedure and a lack of educating a society on 'how to vote', were the main factors of adverse situations. Low interest in elections (voting frequency did not reach 50\%); numerous invalid votes and common complaints on voting procedure did not result in reliable interest of authorities in the above issue. Elections, especially local, should enjoy a big interest of voters (in other words a high voting frequency) as they choose representatives between themselves, as well as a keen interest of candidates, who aspire to become representative of local communities. In general, voting procedures should be simple and legible for all the parties. In addition, their rules should not be changed in the year of elections. It is worth to care more about appropriate civil education regarding elections in order to inform voters about their rights and obligations; thus they would deliberately participate in elections.

What is surprising is the fact that authorities have not questioned the limitation of costs in conducting elections in terms of their quality. According to the Electoral Code (Article 123 and 124) expenses associated with an organization of elections are covered by the state's budget. A draw up of expenses for preparation and conduction of local elections in 2014 was limited to PLN 306,670,900.00. Majority of expenses was planned for coverage of costs associated with: allowances of members of precinct election commissions (circa PLN 115,000,000.00); allowances 
of district election commissions (over PLN 92,000,000.00); print and deliverance of voting cards (over PLN 90,000,000.00) and additional PLN 800,000.00 for printing voting cards' overlays, instruction and information in Braille's alphabet.

Disappointment and problems connected with the conducted voting procedures were a source of other amendments in the Electoral Law. The act dated 25 June 2015 on amendment of the Electoral Code ${ }^{6}$ and signed by the President of the Republic of Poland, Bronisław Komorowski, introduced inter alia the following changes:

a) the homogeneity of cadence of judges of the State Electoral Commission amounting to 9 years as well as setting upper age limit for members of the State Electoral Commission to 70 years (Article 1 Paragraph 21);

b) a change of a number of members of precinct election commissions, in which an overall amount would not exceed 2,000 persons. Each commission shall consist of 8 to 10 members (Article 1 Paragraph 28);

c) the possibility of registration of works of precinct electoral commissions by the union representatives before the beginning of voting (e.g. during preparation of a polling place) and afterwards. The records could be used only as a proof in judicial and prosecution proceedings. For unlawful distribution of records of works of election commission carries a fine of PLN 1,000.00 to PLN 10,000.00 (Article 1 Paragraph 36);

d) a change of ballot boxes - for creation of transparent material (a transparent ballot box) (Article 1 Paragraph 8);

e) a return of the rule of classification of invalid votes (Article 1 Paragraph 28-35);

f) an obligation to notify all the voters about the forthcoming elections. This task is assigned to a vogt (a mayor, a president of a city), who will realize it 21 days before the election day. This will not charge local budgets. (Article 1 Paragraph 4-5).

The above amendments introduced in the Electoral Code (pertaining to regulation of local elections) do not constitute a guarantee of elimination or limitation of risk regarding irregularities that occurred in the local elections in 2014. The proposition of transparent ballot boxes raised some concerns, as it appeared to be expensive. A cost of one transparent ballot box was estimated at PLN 1,000.00 (as per a draft of the act). Taking into account that currently there are 27,435 polling places in Poland, the estimated cost would amount to approximately PLN 28,000,000.00. In order to retain a confidential rule, voting 6 Journal of Laws of 2015, Item 1043 
cards would be placed in envelopes. Polling places will be equipped with envelopes, which will be provided to a voter by request. Undoubtedly, the use of envelopes would make a voting procedure even more complicated. Moreover, it would lengthen the time of counting votes, as well as, it would increase expenses.

\section{CONCLUSION}

The amended Electoral Code is not a final version ${ }^{7}$ and without doubt it cannot be treated as 'the ideal' one either. In fact, none of the amendments gives a possibility to eliminate or limit risk regarding repetition of irregularities in the course of voting. There is a question regarding the probability of creation of 'a good' electoral law since none of the state institutions achieved a success in this field. Numerous propositions of amendments regarding the rules of the electoral law suggested by Polish politicians may indicate inadequacy of the electoral law, on the one hand, as well as, the will to customize it, on the other hand.

For example, in the local elections in 2014, dissatisfaction after the elections (a forgery of results was commonly suggested) a new draft of the act was announced. It regarded the length of cadence of district assemblies selected in the elections conducted in 2014 and in $2015 .{ }^{8}$ On the basis of this act (if it would be applicable) the cadence of 16 district assemblies shall be shortened and the new elections would be announced As for the length of cadence of new elected bodies, it would expire together with the cadence of the other bodies - Municipality and County Councils, vogts, mayors, presidents of the cities elected on 16 November 2014 (Article 1 Paragraph 2 of the Draft act). According to authors of this draft: 'an adoption of this draft of act would impact positively on the society. This draft in the opinion of petitioners would not raise expenses in a budget planned for the conduction of elections of public authorities and referenda'. In addition, the following changes were also proposed: indirect elections of heads of country administration and voivodeship Marshalls, limitation of vogts' cadences to 2 and lengthen of executive bodies' cadences to 5 years. ${ }^{9}$

The multitude and a quality of propositions regarding the amendments of the

7 For instance, on 4 November 2015 the Seym of the Republic of Poland received a petition regarding the novelisation of the Electoral Code in terms of the method of electing senators and councillors of Municipality Councils up to 100,000 inhabitants. In December 2015 this petition was filed to the Commission of the Petition (No. BKSP-145-19/15). Furthermore, the authors of the petition suggested the amendment pertaining to the rule of selection of executive bodies in powiats and district assemblies. In addition, lengthen of their cadence to 5 years was also suggested.

8 Draft act on the length of cadence of district assemblies selected in the elections conducted in 2014 and in 2015. Source: www.sejm.gov.pl

9 Propositions announced by politicians during interviews with them. www.samorzad.infor.pl/ sektor/organizacja/ustroj_i_jednostki/717402 (Accessed on: 12 January 2016) 
electoral law is not always a reflection of a will to 'enhance' it. A lack of proven assumptions for enacting detailed regulations of the electoral law, its application as a tool of gaining a political power (i.a. on the local level), as well as, a lack of civil education results in a low interest of elections (low voting frequency, huge amount of invalid votes). Public authorities should make an effort to constitute 'the ideal electoral law', which would be a basis of other elections.

\section{REFERENCES}

Constitution of the Republic of Poland dated 2 April, 1997(Journal of Laws of 1997, No. 78, Item 483 as amended)

FRAS, J. (2009): Uczestnictwo w wyborach i kampaniach wyborczych po 1989 roku. Wrocław: Wydawnictwo Uniwersytetu Wrocławskiego./ Participation in elections and election campaigns after 1989, ed . J. Fras, Wrocław 2009.

KOMISARSKI. H.(2014): Wybory samorządowe w latach 2002, 2010 i 2014 - praktyczne doświadczenia. Skala i charakter wznoszonych protestów/ The local government elections in the years 2002.2010 and 2014 - practical experience. The scale and nature of the protests. www.prezydent.gov.pl [21.12.2014].

KUMOCH, J., Patologiczny system wyborczy, „Rzeczpospolita”, 9 December 2014/ Pathological electoral system

MP 2012.354: Uchwała PKW z 7 maja 2012 r. w sprawie wytycznych i wyjaśnień dotyczących podziału jednostek samorządu terytorialnego na okręgi wyborcze/ MP 2012.354 : PKW Resolution of 7 May 2012 . On guidelines and explanations concerning the division of local government units to constituencies.

MP 2014.354: Uchwała PKW z 7 maja 2012 r. w sprawie wytycznych i wyjaśnień dotyczących podziału jednostek samorządu terytorialnego na okręgi wyborcze/ MP 2014.354 : PKW Resolution of 7 May 2012 . On guidelines and explanations concerning the division of local government units to constituencies.

IASECKI, A.K., Wybory parlamentarne, samorządowe, prezydenckie 1989-2002,/ parliamentary elections, local , presidential 1989-2002 Torun 2004.Państwowa Komisja Wyborcza. Krajowe Biuro Wyborcze, Informacja o przygotowaniu i przeprowadzeniu wyborów do rad gmin, rad powiatów, sejmików województw, rad dzielnic m.st. Warszawy oraz wyborów wójtów, burmistrzów, prezydentów miast, przeprowadzonych w dniu 16 listopada 2014 r. i w głosowaniu ponownym w dniu 30 listopada 2014r., Warsaw, February 2015, pp. 12-17/ The State Electoral Commission . National Election Office , information about the preparation and conduct of elections to municipal councils , county councils, regional councils, district councils Capital City Warsaw and the election mayors, mayors, held on 16 November 2014 ., And vote again on 
30 November 2014 ., Warsaw, February 2015 , pp . 12-17.

PKW, 2014: www..pkw.gov.pl/2014kat_parlament_europejski/informacjestatystyczne-na temat-wyborow.html [04.11.2014]/ PKW, 2014: The www..pkw. gov.pl / 2014kat_parlament_europejski / information - statistical - on - wyborow. html [ 11.04.2014].

REGULSKI, J. (2000): Samorząd III Rzeczypospolitej. Koncepcje i realizacja. Warszawa: Wydawnictwo Naukowe PWN.

SEJM RP 1998: Sprawozdanie stenograficzne z dnia 18 marca 1998 r./ Parliament.1998: SEJM RP 1998: stenographic report of 18 March 1998.

SEJM RP, 291A: Druk - Sprawozdanie stenograficzne. Parliament, 291A: shorthand report.

SŁOBODZIAN. B. (2005); Współczesny system samorządu terytorialnego w Polsce. Torun, Wydawnictwo Adam Marszałek/ The modern system of local government in Poland.

The Act of 8 March 1990 on the local self-government (Journal of Laws of 2001, No. 142, item 1591, amended)

The Act of 1 April 2011 on amendment of Act - Elections to the Seym of the Republic of Poland, Senate of the Republic of Poland and the Electoral Code, (Journal of Laws of 2011, No. 94, Item 550)

The Act of 15 April 2011 on amendment of Act - Election Code and the Law - regulations implementing the Act - Election Code, (Journal of Laws of 2011. No. 102, Item 588)

The Act of 15 April 2011 on amendment of Act - Election Code and the Law - regulations implementing the Act - Election Code, (Journal of Laws of 2011. No. 147 , Item 881 )

The Act of 29 July 2011 amending the Act on the principles of registration and identification of taxpayers and other acts (Journal of Laws of 2011. No. 171, Item 1016)

The Act of 31 August 2011 on amendment Act - Election Code and other laws, (Journal of Laws of 2011. No. 217, Item. 1281)

The Act of 10 January 2014 on amendment Act - Election Code, (Journal of Laws of 2014, No. 217, Item 179)

The Act of 10 January 2014 on amendment Act - Election Code, (Journal of Laws of 2014, Item 180)

The Act of 11 July 2014 on amendment Act - Election Code and other laws, (Journal of Laws of 2014, Item 1072)

The resolution of the State Election Commission of 7 May 2012 on the guidelines and explanations concerning the division of local government units into constituencies, M.P. of 2012. Item 354; http://pkw.gov.pl/kadencje-2010-2014 